\title{
WAWASAN NUSANTARA SEBAGAI UPAYA MEMBANGUN RASA DAN SIKAP NASIONALISME WARGA NEGARA : SEBUAH TINJAUAN LITERATUR
}

\author{
Lilis Dewi Ratih, Fatma Ulfatun Najicha \\ Fakultas Ekonomi dan Bisnis Universitas Sebelas Maret \\ Fakultas Hukum Universitas Sebelas Maret \\ Email : Lilisdewiratih123@student.uns.ac.id; \\ Fatmanajicha_law@staff.uns.ac.id
}

\begin{abstract}
ABSTRAK
Tantangan dan ancaman yang dihadapi oleh bangsa Indonesia di zaman sekarang ini setidaknya harus dapat dihadapi dengan pemahaman mengenai wawasan nusantara yang memadai sehingga rasa nasionalisme dapat terwujud dengan baik. Pemahaman mengenai wawasan nusantara menjadi salah satu upaya yang bisa dilakukan untuk membangun rasa dan sikap nasionalisme warga negara Indonesia sebagai dasar untuk menjaga persatuan Indonesia dan keutuhan NKRI. Tujuan ditulisnya artikel ini adalah untuk mengetahui bagaimana wawasan nusantara sebagai upaya membangun rasa dan sikap nasionalisme warga negara. Penelitian ini merupakan penelitian studi literatur yang mengulas dan membahas artikel-artikel penelitian sebelumnya mengenai bagaimana wawasan nusantara diperlukan sebagai upaya untuk membangun rasa dan sikap nasionalisme setiap warga negara. Berdasarkan hasil pembahasan menunjukkan bahwa pemahaman wawasan nusantara mempunyai peran yang strategis dalam membangkitkan jiwa nasionalisme terhadap warga negara di tengah-tengah era globalisasi.
\end{abstract}

Kata kunci : wawasan kebangsaan, nasionalisme, warga negara

\begin{abstract}
The challeges and threats faced by the Indonesian nation in this day and age must at least be faced with an adequate understanding of the archipelago so that a sense of nationalism can be realized properly. Understanding the archipelag insight is one of the efforts that can be done to build a sense and attitude of nationalism of Indonesian citizens as the basis for maintaining Indonesian unity and the integrity of the Unitary Republic of Indonesia. The purpose of writing this article is to find out how the insight of the archipelago as an effort to build a sense and attitude of citizens nationalis. This research is a literature study that reviews and discusses previous research articles on how insight into the archipelago is needed as an effort to build a sense and attitude of nationalism for every citizen. Based on the results of the discussion, it shows that understanding the archipelago has a strategis role in awakening the spirit of nationalism to citizens in the midst of the era of globalization.
\end{abstract}

Keywords : Archipelago insight, nationalism, citizen 


\section{PENDAHULUAN}

Di era dewasa ini yang sangat erat kaitannya dengan globalisasi dan juga banyak perubahan yang sangat dinamis di berbagai bidang kehidupan, bangsa Indonesia dihadapkan dengan berbagai persoalan dan tantangan yang hadir baik yang berasal dari internal maupun eksternal. Permasalahan yang ada secara internal diantaranya adalah semakin memudarnya pilar-pilar dalam kehidupan berbangsa dan bernegara yang berhubungan dengan turunnya komitmen terhadap nilai-nilai dasar kehidupan dan norma-norma yang sudah lalu dijadikan sebagai pegangan dalam kehidupan berbangsa dan bernegara. Rendahnya komitmen tersebut salah satunya dapat terlihat dari semakin lemahnya kewibawaan hukum akibat rendahnya moralitas para penegak hukum, meningkatnya angka kemiskinan, meningkatnya kriminalitas, meningkatnya potensi disintegrasi bangsa karena ikatan primodialisme etnis dan keagamaan yang menguat hingga degradasi moral dan karakter di kalangan anak bangsa (Abdulgani, 1995) yang semakin mengancam keutuhan dan kedaulatan Negara Kesatuan Republik Indonesia

Tantangan dan ancaman yang datang dari bangsa luar pun tidak kalah dengan tantangan dan ancaman yang berasal dari bangsa sendiri, terutama dengan adanya tantangan globalisasi yang dapat menyebabkan semakin meluasnya sistem demokrasi liberal yang terjadi pada berbagai sendi kehidupan baik di bidang ekonomi, politik, sosial-budaya, dan juga keamanan dan pertahanan yang dapat menghadirkan krisis multi-dimensional. Hampir seluruh ancaman dan tantangan telah menyebabkan ketegangan dan tarik menarik kekuatan antara nilai-nilai kearifan lokal dengan nilainilai global.

Berdasarkan kenyataan yang terjadi seperti yang dinyatakan di atas, hal itu menjadi dasar pemikiran dari para akademisi untuk mengajak revitalisasi membangun karakter kebangsaan melalui suatu wadah pendidikan sebagai bagian dari upaya membina dan mengembangkan nilainilai kebangsaan dan karakter kebangsaan
(Puskur, 2010) (Suyatno, 2009). Pada lingkup pendidikan tingkat tinggi, telah ditetapkan UU RI No. 12 Tahun 2012 tentang Pendidikan Tinggi yang secara langsung menyebutkan bahwa kurikulum nasional setiap perguruan tinggi mewajibkan agar memuat mata kuliah Pancasila, Kewarganegaraan, Agama dan Bahasa Indonesia. Pendidikan Kewarganegaraan saat ini menjadi sangat penting di tengah kondisi kehidupan bangsa Indonesia tanpa bermaksud mengacuhkan urgensi tiga mata kuliah wajib lainnya. Untuk dapat memenuhi tuntutan perkembangan zaman sekarang ini, perlu adanya pengembangan lebih lanjut mengenai substansi kajian yang dapat memungkinkan pelaksanaan perkuliahan Pendidikan Kewarganegaran di perguruan tinggi berjalan efektif dan sesuai dengan tujuan dan fungsinya sebagai sarana pembinaan mahasiswa sebagai generasi penerus bangsa yang sadar dan peduli dengan keutuhan dan keberlangsungan kehidupan bangsa dan negara Indonesia. Untuk mewujudkan tujuan ini, Kementerian PendidikanMdan Kebudayaan Direktorat Jenderal Pendidikan Tinggi, (2013), dalam substansi materi Pendidikan Kewarganegaraan tetap mengadakan materi Wawasan nusantara sebagai salah satu topik yang diharapkan dapat memperkokoh kesadaran mahasiswa akan pentingnya persatuan Indonesia dan keutuhan NKRI. Pemahaman mengenai wawasan nusantara menjadi salah satu upaya yang bisa dilakukan untuk membangun rasa dan sikap nasionalisme di kalangsa bangsa Indonesia sebagai dasar untuk menjaga persatuan Indonesia dan keutuhan NKRI. Pemahaman wawasan nusantara dapat diberikan kepada warga negara melalui berbagai cara, salah satunya adalah melalui pendidikan. melalui pendidikan, pemahaman tentang wawasan nusantara dan sikap nasionalisme berusaha diwujudkan dan diimplementasikan. Upaya tersebut dimanifestasikan ke dalam tujuan pendidikan nasional. Hal ini terbukti dengan tujuan pendidikan yang juga harus dilandasi dengan jiwa Pancasila dan UndangUndang Dasar 1945. Seperti yang 
termuat di dalamUndang-Undang RI No. 20 Tahun 2003 tentang Sistem Pendidikan Nasional, Bab 1 Ketentuan Umum Pasal 1 Ayat (2) yang berbunyi "Pendidikan nasional adalah pendidikan yang berdasarkan Pancasila dan Undang-Undang Dasar Negara Republik Indonesia Tahun 1945, yang berakar pada nilai agama, kebudayaan nasional Indonesia dan siap terhadap tuntutan perubahan aman".

Selain itu, wawasan nusantara sebagai konsepsi juga dirumuskan sebagai salah satu upaya dalam rangka menumbuhkan dan membentuk karakter kebangsaan generasi muda. Setiawan \& Setiawan (2014) memaknai karakter sebagai cara berpikir dan berperilaku yang unik tiap individu untuk hidup berkerja sama, baik dalam lingkup keluarga, masyarakat, bangsa dan negara. Individu yang berkarakter baik adalah individu yang dapat mengambil keputusan dan siap bertanggungjawab setiap akibat dari keputusan yang diambilnya.

Melalui pendidikan formal, mahasiswa telah mengenal Indonesia dengan konsepsi wawasan nusantaranya. Akan tetapi yang lebih penting dalam hal ini adalah bagaimana nilai-nilai nasionalisme dan semangat kebangsaan yang terkandung dalam konsepsi tersebut dapat menginternalisasi ke dalam jiwa setiap warga negara dan mengimplementasikan ke kehidupannya sehari-hari. nilai yang ada dalam jiwa dideskripsikan sebagai sesuatu yang berharga menjadi landasan dalam menentukan perbuatan baik-buruk, benar-salah atau yang sering disebut dengan moral (Kirschenbaum, 1995). Terlebih pada era dewasa ini, wawasan nusantara sangat diperlukan dalam rangka menghadapi ancaman dan tantangan sebagai pengaruh dari adanya modernisasi dan globalisasi yang tidak hanya memberikan pengaruh positif, tetapi juga memberi pengaruh yang negatif seperti individualisme, hedonisme, konsumerisme dan westernisasi yang dapat menyebabkan degradasi moral dan mengikis rasa nasionalisme.

\section{METODE}

Penelitian ini merupakan penelitian studi literatur yang mengulas dan membahas artikel-artikel penelitian sebelumnya mengenai bagaimana Wawasan nusantara dapat membangun dan memperkokoh rasa nasionalisme warga negara. Artikel ini akan lebih berpusat untuk mendiskusikan hasil-hasil penelitian yang terdahulu terkait dengan upaya membangun rasa dan sikap nasionalisme setiap warga negara melalui pembelajaran Wawasan nusantara untuk mewujudkan warga negara yang mencintai tanah airnya dan nilai-nilai dan budaya yang ada di tanah air atau bangsa serta dengan sukarela menjaga persatuan Indonesia dan keutuhan NKRI. Adapun teknik pengumpulan datanya dengan menggunakan dokumentasi seperti berupa buku-buku atau e-book dan artikelartikel yang relevan.

\section{HASIL}

Wawasan nusantara merupakan sudut pandang suatu bangsa mengenai diri dan lingkungannya yang dijabarkan dari dasar falsafah dan sejarah bangsa itu sesuai dengan kondisi keberadaan dan kondisi geografi negaranya untuk mencapai tujuan atau cita-cita nasionalnya.

Berdasarkan Ketetapan MPR Tahun 1993 dan 1998 tentang GBHN menyatakan bahwa Wawasan Nusantara merupakan wawasan nasional yang bersumber pada Pancasila dan berdasarkan UUD 1945 adalah cara pandang dan sikap bangsa Indonesia tentang diri dan lingkungannya dengan mengutamakan persatuan dan kesatuan bangsa serta kesatuan wilayah dalam menyelenggarakan kehidupan bermasyarakat, berbangsa dan bernegara untuk mencapai tujuan bangsa.

Menurut M. Panggabean (1979 : 349) Wawasan Nusantara adalah doktrin politik bangsa Indonesia untuk mempertahankan kelangsungan hidup Negara Republik Indonesia, yang didasarkan pada Pancasila dan UUD 1945 dengan memperhitungkan pengaruh geografi, ekonomi, demografi, teknologi dan kemungkinan strategik yang tersedia Dapat 
dikatakan pula bahwa Wawasan Nusantara merupakan geopolitik Indonesia. Secara intern nilai yang terkandung di dalam wawasan nusantara telah diintegrasikan ke dalam lima aspek diantaranya yaitu kesatuan wilayah, kesatuan bangsa, kesatuan ekonomi, kesatuan budaya, dan kesatuan pertahanan. Dengan kelima aspek yang telah terintegrasi tersebut nantinya diharapkan secara bersama-sama dapat memberikan dan memperjelas pemahaman mengenai wawasan nusantara lebih lanjut lagi dengan melihat semua aspek tersebut sehingga memperkokoh rasa persatuan dan rasa cinta tanah air. Sementara secara ekstern nilai integrasi diupayakan dengan turut serta mewujudkan ketertiban dunia yang berdasarkan perdamaian abadi dan keadilan sosial.

Indonesia adalah bangsa dengan masyarakat yang multikultural dan majemuk. Masyarakat multikultural adalah suatu masyarakat yang hidup dalam suatu tempat dengan berbagai kebudayaan yang berbeda. Masyarakat multikultural biasanya menganut paham multikulturalisme, yaitu anggapan bahwa setiap budaya memiliki kedudukan yang sama derajatnya dan kelebihannya tersendiri tanpa menganggap rendah selain budayanya sendiri. Bangsa Indonesia dalam membina dan membangun atau menyelenggarakan kehidupan berbangsa dan bernegara selalu mengutamakan persatuan dan kesatuan. Gagasan untuk menjamin persatuan dan kesatuan dalam kebhinekaan tersebut merupakan cara pandang bangsa Indonesia tentang identitas diri dan lingkungannya yang dikenal dengan istilah Wawasan Kebangsaan atau Wawasan Nasional Indonesia dan dinamakan Wawasan Nusantara.

Wawasan nusantara yang merupakan pedoman jiwa nasionalisme ini memiliki dua tujuan utama, yaitu tujuan nasional dan tujuan ke dalam. Berdasarkan Pembukaan uud 1945, wawasan nusantara memiliki tujuan nasional untuk melindungi segenap bangsa Indonesia dan seluruh tumpah darah Indonesia. Dan untuk mewujudkan kesejahteraan umum, mencerdaskan kehidupan bangsa, dan ikut melaksanakan ketertiban dunia yang berdasarkan kemerdekaan perdamaian abadi dan keadilan sosial. Sementara tujuan ke dalam memiliki tujuan untuk mewujudkan kesatuan segenap aspek kehidupan baik alamiah maupun sosial. Indonesia menjunjung tinggi kepentingan masyarakat, kepentingan kawasan untuk menyelenggarakan dan membina kesejahteraan, kedamaian dan budi luhur serta martabat seluruh manusia di dunia.

Adapun faktor yang memengaruhi wawasan nusantara diantaranya adalah faktor wilayah yang meliputi asas kepulauan, kepulauan Indonesia, konsep tentang wilayah lautan dan karakteristik wilayah nusantara. Faktor yang kedua adalah faktor geologi dan geostrategi. Geopolitik menjelaskan dasar pertimbangan dalam menentukan alternatif kebijakan nasional untuk mewujudkan tujuan tertentu. Sedangkan geostrategi adalah politik dalam pelaksanaan, yaitu bagaimana mencapai tujuan atau sasaran yang ditetapkan sesuai dengan kebutuhan politik. Kemudian, faktor ketiga yang memengaruhi wawasan nusantara adalah faktor perkembangan wilayah Indonesia dan dasar hukumnya.

Filsuf Prancis, ernest Renan, memberi pernyataan bahwa nasionalisme adalah suatu kesadaran untuk bersatu tanpa adanya dorongan atau paksaan yang dituntut oleh obsesi untuk mewujudkan kepentingan yang luhur, yang pada akhirnya menciptakan sebuah identitas nasionnal atau identitas sebuah bangsa.

John Stuart Mill (dalam Hosbawn, 1992) seorang ahli tata negara, merumuskan bangsa sebagai keinginan dari anggota anggota nasionalitas untuk berada di bawah pemerintahan yang sama dan pemerintahan yang didirikan itu hendaklah berasal dari mereka sendiri atau sebagian dari mereka secara eksklusif.

Dalam Kamus Besar Bahasa Indonesia(Depdikbud,1997), Nasionalisme didefinisikan sebagai kesadaran keanggotaan dalam suatu bangsa yang secara potensial atau aktual secara bersama-sama untuk mencapai, mempertahankan, dan mengabadikan identitas, integritas, kemakmuran, dan kekuatan bangsa itu, yakni semangat kebangsaan. 
Berbagai pengertian nasionalisme yang diungkapkan oleh para ahli yang pada intinya mengarah pada suatu konsep mengenai jati diri kebangsaan yang memiliki fungsi dalam penetapan identitas individu di antara seluruh masyarakat dunia. Nasionalisme Indonesia menggambarkan ikatan budaya yang menyatukan dan mengikat rakyat Indonesia yang majemuk menjadi satu bangsa dalam ikatan negarabangsa.

Jiwa nasionalisme akan tumbuh dan berkembang di suatu lingkungan masyarakat itu berada terlebih jika ada ancaman yang dianggap dapat menganggu dan mengancam dirinya. Jiwa nasionalisme ini mulai hadir saat manusia hidup secara bersama-sama yang mendiami suatu daerah dan wilayah tertentu dan hidup secara tidak nomaden. Kemudian ketika ada ancaman yang berasal dari luar yang dirasa membahayakan mereka lalu mulai tumbuhlah semangat nasionalisme itu yang dilakukan untuk mempertahankan diri dari segala ancaman marabahaya.

Untuk menjunjung tinggi jiwa nasionalisme Indonesia, wawasan nusantara dapat diimplementasikan ke dalam kehidupan sehari-hari oleh setiap warga negara dengan menjadikan Panacasila sebagai pedoman hidup bermasyarakat, berbangsa, dan bernegara. Hal itu dapat dicerminkan seperti dengan nilai religius, kekeluargaan atau kekerabatan, bersikap saling menghargai dan saling toleransi dengan semua orang tanpa pandang bulu. Di samping itu, wawasan nusantara juga dapat diimplementasikan dengan membela bangsa Indonesia, mengenalkan dan membawa citra yang baik bangsa Indonesia ke dunia luar, dan selalu mementingkan kepentingan umum terlebih dahulu di atas kepentingan pribadi atau golongan tertentu.

Wawasan nusantara memiliki fungsi sebagai pedoman, motivasi, dan dorongan dalam menentukan segala keputusan, kebijaksanaan, tindakan dan perbuatan bagi para penyelenggara negara di tingkat pusat dan daerah maupun bagi seluruh rakyat Indonesia dalam kehidupan bermasyarakat, berbangsa, dan bernegara. Wawasan nusantara memiliki tujuan untuk dapat mewujudkan jiwa nasionalisme yang tinggi di segala bidang kehidupan masyarakat Indonesia yang mengutamakan kepentingan nasional daripada kepentingan pribadi atau golongan tertentu. Pendidikan merupakan salah satu faktor penting dalam menentukan kemajuan suatu bangsa karena melalui pendidikan dapat membuat masyarakat atau warga negara menjadi berpikir lebih maju dan kritis, bermoral, dan mampu untuk berkompetisi dengan negara lain (Najicha, 2017). Pada hakikatnya wawasan nusantara adalah keutuhan nusantara, dalam pengertian cara pandang yang selalu utuh dan bersifat menyeluruh dalam lingkup nusantara demi kepentingan nasional. Hal tersebut mengimpilkasikan bahwa setiap warga negara harus berpikir, bersikap, dan bertindak secara utuh dan menyeluruh demi kepentingan bangsa dan negara.

\section{KESIMPULAN}

Wawasan nusantara merupakan sudut pandang suatu bangsa mengenai diri dan lingkungannya yang dijabarkan dari dasar falsafah dan sejarah bangsa itu sesuai dengan kondisi keberadaan dan kondisi geografi negaranya untuk mencapai tujuan atau cita-cita nasionalnya. Faktor-faktor yang memengaruhi memudarnya pemahaman wawasan nusantara dan rasa nasionalisme adalah disebabkan baik faktor internal maupun faktor eksternal dimana nasionalisme ini menurun karena adanya beberapa faktor yang menghambat untuk mewujudkan nasionalisme diantaranya karena penyelenggara negara dan masyarakat kurang memahami apa itu konsep kedaulatan negara kita sebagai negara kepulauan, adanya budaya egosentrisme, etnonasionalisme, dan pemahaman konsep untuk mengimpelementasikan otonomi daerah yang sempit yang memunculkan sikap etnosentrisme pada masyarakat lokal. Penerapan ke masyarakat mengenai wawasan nusantara dalam kehidupan bermasyarakat, berbangsa, dan bernegara dapat dilakukan baik melalui pendidikan formal maupun pendidikan nonformal dengan mengenalkan 
keberadaan negara kita sebagai Negara Kepulauan yang berdaulat sehingga kita sebagai masyarakat bangsa Indonesia dapat menghadapi ancaman dan tantangan yang datang baik dari dalam maupun dari luar.

\section{DAFTAR PUSTAKA}

Abdulgani, R. (1995). Pemantapan Jiwa Nasionalisme dan Abad ke XXI Menghadapi Era Globalisasi, termuat dalam Siswono Yudohusodo, dkk., Nasionalisme dalam Era Globalisasi. Yayasan Widya Patria.

Depdikbud. (1997). Kamus Besar Bahasa Indonesia.

Kirschenbaum. (1995). 100 Ways to Enhance Values and Morality in Schools and Youth Settings. Allys \& Bacon.

Lukum, R. (2005). Upaya Peningkatan Pemahaman Wawasan Nusantara Sebagai Sarana dalam Meningkatkan Semangat Nasionalisme Bagi Warga Negara Indonesia. Repository Universitas Negeri Gorontalo.

Puskur. (2010). Pendidikan Budaya dan Karakter Bangsa. PUSKUR.

Setiawan, D., \& Setiawan, F. (2014). Pendidikan Karakter dalam Perspektif Kewarganegaraa (Larispa (ed.)).

Suyatno. (2009). Urgensi Pendidikan Karakter. Depdiknas.

Kementerian Pendidikan dan Kebudayaan Direktorat Jenderal Pendidikan Tinggi. (2013). Substansi Materi Pendidikan Kewarganegaraan. Kementerian $\mathrm{P}$ dan K Dirjen Dikti.

Ketetapan MPR Tahun 1993 dan 1998. (n.d.). Ketetapan MPR Tahun 1993 dan 1998 tentang GBHN.

Undang-Undang RI No. 20 Tahun 2003. (2003). Undang-Undang RI No. 20 Tahun 2003 tentang Sistem Pendidikan Nasional, Bab 1 Ketentuan Umum Pasal 1 Ayat (2).

UU RI No. 12 Tahun 2012. (2012). UU RI No. 12 Tahun 2012 tentang Pendidikan Tinggi.
Najicha, F. U. (2017). Aku Generasi Unggul Masa Depan, Generasi Muda Harapan Bangsa.

https://www.academia.edu/39981475/Ak u_Generasi_Unggul_Masa_Depan_Gene rasi_Perubahan_Oleh_Fatma_Ulfatun_N ajicha, diakses 13 Juni 2021. 